\title{
Protective effect of Litsea japonica fruit flesh extract on indomethacin-induced gastritis in rats
}

\author{
Sung-Hwan Park ${ }^{1}$, In-Jae Park ${ }^{1}$, Ji-Hyun Yun ${ }^{1}$, Goo-Hee Choi ${ }^{1}$, Hyun-Jung Kim ${ }^{1}$, \\ Yun-Hee $\mathrm{Seo}^{2}$, Ju-Hyun $\mathrm{Cho}^{1 *}$ \\ ${ }^{1}$ Hurum Central research institute Co., Ltd., Segwipo 63608, Korea \\ ${ }^{2}$ EBO Co., Ltd., Cheongju 28116, Korea
}

\section{흰쥐에서 인도메타신으로 유발된 위염에 대한 까마귀쪽나무열매추출물의 보호효과}

\author{
박성환 ${ }^{1} \cdot$ 박인재 $^{1} \cdot$ 윤지현 $^{1} \cdot$ 최구희 $^{1} \cdot$ 김현정 $^{1} \cdot$ 서윤희 $^{2} \cdot$ 조주현 $^{1 *}$ \\ ${ }^{1}$ (주)휴럼중앙연구소, ${ }^{2}$ (주)이비오
}

\begin{abstract}
The objective of this study was to investigate the inhibitory effects of Litsea japonica fruit flesh extract (LJF-HE) on gastritis in an indomethacin-induced SD rat model. Rats were randomly divided into six groups: G1 (normal group), G2 (control group, indomethacin-induced gastritis), G3 (positive group, indomethacin-induced gastritis and ranitidine $50 \mathrm{mg} / \mathrm{kg}$ ), G4 (LJF-HE-L group, indomethacin-induced gastritis and $L$. japonica fruit flesh extract at $30 \mathrm{mg} / \mathrm{kg}$ ), G5 (LJF-HE-M group, indomethacin-induced gastritis and $L$. japonica fruit flesh extract at $60 \mathrm{mg} / \mathrm{kg}$ ), G6 (LJF-HE-H group, indomethacin-induced gastritis and $L$. japonica fruit flesh extract at $120 \mathrm{mg} / \mathrm{kg}$ ). In the group treated with LJF-HE (G4, G5, and G6), gastric mucosal damage, gastric juice secretion and pepsin activity were significantly decreased compared to the control group. Additionally, there were decreases in the expression of cholecystokinin 2 receptor (CCK-2r), histamine receptor $\mathrm{H} 2(\mathrm{H} 2 \mathrm{r})$ and $\mathrm{H}+/ \mathrm{K}+$ ATPase in the gastric lesions. The plasma levels of TNF- $a$ and IL-1 $\beta$ significantly decreased in LJF-HE (G4, G5, and G6) treated groups compared with control. The plasma level of PGE2 was also significantly increased by LJF-HE (G5 and G6). These results suggest that LJF-HE (G4, G5, and G6) has the ability to inhibit on indomethacin-induced gastritis.
\end{abstract}

Key words : Litsea japonica, gastritis, indomethacin, gastric ulcer

\section{서 론}

위 질환에는 위궤양, 위암, 위염, 위산과다증 등이 있으 며, 이 중 위염은 조직학적으로 위 점막에 염증 세포의 침윤 이 있는 상태를 지칭하며, 급성위염과 만성위염으로 구분 할 수 있다. 위염의 증상으로는 속쓰림, 복부불쾌감, 구역질, 구토, 복부팽만감 등이 있는 것으로 알려져 있다 $(1,2)$. 만성

*Corresponding author. E-mail : dusvnd608@hanmail.net Phone : 82-70-4231-1078, Fax : 82-64-767-1076

Received 3 November 2017; Revised 23 November 2017; Accepted 27 November 2017.

Copyright (c) The Korean Society of Food Preservation. All rights reserved.
위염은 노화에 의한 위 점막 위축 및 헬리코박터 파이로니 감염 등의 원인으로 유발되어지고, 급성위염은 비스테로이 드성 항염증제(non-steroidal anti-inflammatory drugs, NSAIDs)의 장기간 사용, 과다한 알코올 섭취 및 스트레스 등과 같은 원인으로 유발된다 $(3,4)$. 비스테로이드 항염증제 는 위장에서 에이코사노이드(eicosanoid)의 생합성을 담당 하는 효소인 cyclooxygenase-1(또는 COX-1)을 억제하여 소 화성궤양 형성 가능성을 높이는 것으로 알려져 있다(5) 또한 인도메타신(indomethacin), 아스피린(aspirin), 록소프 로펜(loxoprofen), 디클로페낙(diclofenac)과 같은 NSAIDs 는 프로스타글란딘(prostaglandin)이라고 불리는 위 보호물 질을 감소시키며, 단기간 사용은 일반적으로 위험하지 않 으나 정기적 사용은 위염을 유발 가능성이 있는 것으로 
알려져 있다(6).

현재 시판되어지고 있는 위염치료제는 우수한 효능을 가지고 있으나, 장기적인 복용으로 인한 소화기질환, 두드 러기 등의 부작용(7-9)과 비용부담 등에 대한 문제점이 대 두대면서 안전성이 확보된 천연물유래의 위장건강소재에 대한 관심이 높아져 다양한 연구가 진행되어져왔다. 특히 현재까지 위 건강에 대한 건강기능식품 소재로 연구된 소재 로는 위 점막 내 헬리코박터균 증식을 억제하고 위 점막을 보호하여 위 건강에 도움을 줄 수 있는 감초추출물(10,11), 위 불편함 개선에 도움을 줄 수 있는 매스틱검 $(12,13)$, 위 점막을 보호하여 위 건강에 도움을 주는 비즈왁스알코올 $(14,15)$, 담즙분비를 촉진하여 지방소화에 도움을 줄 수 있 는 아티초크추출물(16) 등이 있다.

까마귀쪽나무(Litsea Japonica)는 제주도 해안가를 중심 으로 자생하고 있는 자원(17)으로 염증완화, 관절염완화, 통증개선, 설사 등 생리활성에 대한 연구가 수행되어져 왔 으나(18-22), 위 기능개선에 대한 체계적인 연구는 아직 이 루어지지 않았다. 이에 본 연구에서는 까마귀쪽나무추출물 의 다양한 생리활성 중 위염 유발 원인의 하나인 화학적인 원인 모델인 인도메타신으로 유도된 위염 동물모델에서 위 손상에 대한 보호 효과 및 위 보호에 대한 작용기전을 확인하여 위 건강에 도움을 줄 수 있는 건강기능식품소재 개발의 자료로 활용하고자 하였다.

\section{재료 및 방법}

\section{까마귀쪽나무열매추출물 (LJF-HE) 제조}

제주도에 자생하고 있는 까마귀쪽나무열매(2015년)를 채취하여 열매를 종자와 과육으로 분리 후 과육 부분을 동결건조하였다. 까마귀쪽나무열매 과육 동결건조물 $(1,000 \mathrm{~g})$ 을 $\mathrm{n}$-hexane으로 실온에서 24 시간 동안 추출 후 여과 및 감압 농축하여 n-hexane을 제거하고 추출물을 제조 하였다. 이때 까마귀쪽나무열매추출물의 n-hexan 잔류량이 식품의약품안전처의 건강기능식품소재로 활용이 가능한 규격인 $0.005 \mathrm{~g} / \mathrm{kg}$ 이하를 충족하는 $0.001 \mathrm{~g} / \mathrm{kg}$ 로 분석되었 다. 까마귀쪽나무열매추출물(LJF-HE)의 수율은 약 $30.6 \%$ $(\mathrm{w} / \mathrm{w})$ 이고, 사용 전까지 $4^{\circ} \mathrm{C}$ 에서 보관하였다.

\section{까마귀쪽나무열매추출물(LJF-HE)의 지표성분(Hamabiwalactone B) 함량분석}

지표성분 Hamabiwalactone $\mathrm{B}(99.0 \%$, (주)천연물화학, Daejeon, Korea)를 dichloromethan(Fisher Scientific Korea Ltd., Seoul, Korea) $5 \mathrm{~mL}$ 로 정용하여 표준원액을 제조하고, methanol(Fisher Scientific Korea Ltd.)로 희석하여 12.5, 25, $50,100,200 \mu \mathrm{g} / \mathrm{mL}$ 의 농도로 표준용액을 제조하였다. 시료 (LJF-HE) 약 $150 \mathrm{mg}$ 을 무게 칭량 후 ethanol $15 \mathrm{~mL}$ 을 넣어 ultrasonic cleaner(Powersonic 420, Hwashin Tech, Seoul, Korea)에서 30 분간 추출하고 $25 \mathrm{~mL}$ 로 정용하여 $0.45 \mu \mathrm{m}$ syringe filter(PTFE, Whatman, Cardiff, Wales, UK)로 여과 후 시험용액으로 사용하였다. 상기 제조된 표준용액과 시 험용액은 HPLC(Waters 2695/996, Milford, MA, USA)로 함 량을 분석하였으며, 검출파장은 $254 \mathrm{~nm}$ 로 설정하였다. 컬 럼은 Cadenza $\mathrm{C}_{18}(4.6 \mathrm{~mm} 150 \mathrm{~mm}, 5$ m, Imtakt, Japan)을 사용하였고, 온도는 $30^{\circ} \mathrm{C}$ 로 유지하였다. 이동상조건은 $\mathrm{H}_{2} \mathrm{O}(0.5 \%$ Acetic acid)와 acetonitrile(Fisher Scientific Korea Ltd.)을 구배용매 조성법으로 유속을 $1.2 \mathrm{~mL} / \mathrm{min}$ 속도로 $10 \mu \mathrm{L}$ 를 주입하여 아래 식으로 함량을 구하였다(18).

$$
\text { Hamabiwalactone } B(\mathrm{mg} / \mathrm{g})=\frac{\mathrm{a} \times \mathbf{b} \times \mathbf{c} \times \mathbf{d}}{\mathrm{e}}
$$

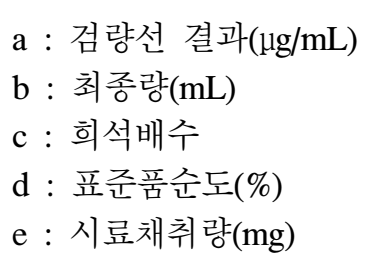

\section{인도메타신에 의한 위염 유발}

실험동물(주대한바이오링크, Eumseong, Korea)은 200-220 $\mathrm{g}$ 의 7 주령 수컷 $\mathrm{SD}$ rat를 온도 $23 \pm 3^{\circ} \mathrm{C}$, 습도 $50 \pm 5 \%$ 에서 light cycle은 12시간으로 유지하면서 순화시킨 후에 무작위 법을 이용하여 Table 1과 같이 군당 8 마리씩 군 분리를 실시하였다. 군 분리는 정상군 $(\mathrm{G} 1$, normal), 대조군 $(\mathrm{G} 2$, control, 인도메타신 위염 유발), 양성대조군(G3, ranitidine, $50 \mathrm{mg} / \mathrm{kg}$, 인도메타신 위염 유발), 까마귀쪽나무열매추출 물 저농도 투여군(G4, LJF-HE-L, $30 \mathrm{mg} / \mathrm{kg}$, 인도메타신 위 염 유발), 까마귀쪽나무열매추출물 중농도 투여군(G5, LJF-HE-M, $60 \mathrm{mg} / \mathrm{kg}$, 인도메타신 위염 유발), 까마귀쪽나 무열매추출물 고농도 투여군(G6, LJF-HE-H, $120 \mathrm{mg} / \mathrm{kg}$, 인도메타신 위염 유발)의 총 6군으로 구성하여 (주)이비오 실험동물운영위원회(EBOA-2016-05-02)의 승인을 받아 진 행하였다. $\mathrm{G} 1$ 과 $\mathrm{G} 2$ 그룹은 $0.5 \% \mathrm{CMC}$ 를, $\mathrm{G} 3$ 그룹과 까마귀 쪽나무열매추출물 그룹(G4, G5, and G6)들은 7일 동안 시험 물질을 매일 1 회씩 경구 투여하였으며, 시험기간 동안 일반 증상 및 사망동물의 유무를 관찰하였다. 실험 종료 전 16시 간 동안 절식 시킨 다음 인도메타신을 $4 \mathrm{~mL} / \mathrm{kg}$ 로 피하투여 (인도메타신 $25 \mathrm{mg}$ 을 $4 \mathrm{~mL}$ 에 녹여 사용)하였으며, 인도메 타신 투여 3시간 후 마취하고 개복하여 유문부를 결찰하고 4 시간 후 시험동물을 희생시켰다. 동물을 희생시키기 전에 복대동맥에서 혈액을 채취하여 EDTA가 처리된 tube에 넣 고 roller에서 10 분간 반응 시킨 후, $1,800 \times g$ 으로 20 분간 원심분리하여 혈장을 채취하였다(23,24). 
Table 1. Gastrointestinal function by LJF-HE in experimental groups and dosage

\begin{tabular}{cccccc}
\hline & Experimental group & $\begin{array}{c}\text { Test } \\
\text { animal }\end{array}$ & Sex & $\begin{array}{c}\text { No of } \\
\text { animals }\end{array}$ & $\begin{array}{c}\text { Dose volume } \\
(\mathrm{mg} / \mathrm{kg})\end{array}$ \\
\hline G1 $^{1)}$ & Normal group & SD rat & male & 8 & 0 \\
G2 & Control group & SD rat & male & 8 & 0 \\
G3 & Positive group (ranitidine) & SD rat & male & 8 & 50 \\
G4 & LJF-HE Low-concentration & SD rat & male & 8 & 20 \\
G5 & LJF-HE Medium-concentration & SD rat & male & 8 & 60 \\
G6 & LJF-HE High-concentration & SD rat & male & 8 & 120 \\
\hline
\end{tabular}

${ }^{1)} \mathrm{G} 1$ (normal, vehicle), G2 (control, indomethacin-induced gastritis), G3 (ranitidine $50 \mathrm{mg} / \mathrm{kg}$, indomethacin-induced gastritis and pretreatment of ranitidine $50 \mathrm{mg} / \mathrm{kg}$ ), G4 (LJF-HE-L, indomethacin-induced gastritis and pretreatment of LJF-HE $30 \mathrm{mg} / \mathrm{kg}$ ), G5 (LJF-HE-M, indomethacin-induced gastritis and pretreatment of LJF-HE $60 \mathrm{mg} / \mathrm{kg}$ ), G6 (LF-HE-H, indomethacin-induced gastritis and pretreatment of LJF-HE $120 \mathrm{mg} / \mathrm{kg}$ ) groups.

\section{위 염증 길이 측정 및 위염 억제율}

6개 그룹(G1-G6)의 실험동물을 희생시킨 후 개복하여 위를 적출하였다. 적출한 위로부터 위액을 채취한 후, 위는 대만곡부를 따라 종 절개하여 위 내용물을 제거하고 식염수 로 세척한 후, cork board에 펼쳐서 사진을 촬영하였다. 위 점막 손상(위궤양, 출혈부위) 측정의 길이 $(\mathrm{mm})$ 는 촬영된 사진으로 Image J 프로그램(NIH, Bethesda, MD, USA)을 사용하여 측정하였으며, 점상출혈인 경우 5 개를 $1 \mathrm{~mm}$ 로 계산하여 측정하였다. 또한 손상된 길이를 아래의 식으로 계산하여 위염 억제율(\%)로 나타냈다(25).

$$
\begin{aligned}
& \text { 위염 억제 율 }(\%)= \\
& \frac{\text { 대조군의 염증길이 }(\mathrm{mm}) \text {-시험물질처리군의 염증길이 }(\mathrm{mm})}{\text { 대조군의 염증길이 }(\mathrm{mm})} \times 100
\end{aligned}
$$

\section{위액량 및 펩신 활성도 측정}

6개 그룹(G1-G6)의 실험동물을 희생시킨 후 위의 대만곡 부를 따라 절개하기 전에 pipette을 이용하여 위액을 수집하 고 위액량 $(\mathrm{mL})$ 을 측정하였다. 또한 6개 그룹(G1-G6)의 실 험동물로부터 채취한 위액 $0.01 \mathrm{~mL}$ 에 hemoglobin(SigmaAldrich, St. Louis, MO, USA) 기질 용액 $2.5 \mathrm{~mL}$ 과 0.01 $\mathrm{N} \mathrm{HCl}$ (Sigma-Aldrich) $0.49 \mathrm{~mL}$ 을 가하여 $37^{\circ} \mathrm{C}$ 에서 10 분간 반응시키고 5\% trichloroacetic acid(Sigma-Aldrich) $5 \mathrm{~mL}$ 을 첨가하여 반응을 종결 시킨 후, $4,000 \times g$ 에서 20 분간 원심분 리하여 얻은 상등액 $2.5 \mathrm{~mL}$ 에 $0.5 \mathrm{~N} \mathrm{NaOH}$ (Sigma-Aldrich) $5 \mathrm{~mL}$ 과 3배로 희석된 Folin Ciocalteau's agent(SigmaAldrich) $1.5 \mathrm{~mL}$ 을 가하여 5-10분간 반응 시킨 후 $595 \mathrm{~nm}$ 에 서 흡광도를 측정하였다. 표준용액은 $0.2 \mathrm{~N} \mathrm{HCl}$ 에 용해시킨 tyrosine(Sigma-Aldrich)용액 $1 \mathrm{~mL}$ 에 $0.2 \mathrm{~N} \mathrm{HCl} 4 \mathrm{~mL}$ 을 가하 여 $0,0.5,1 \mathrm{mM}$ 의 농도를 조제하고, 펩신 활성은 $\mathrm{mg}$ tyrosine produced/h로 구하였다(26).

\section{혈장 위염지표분석}

6개 그룹(G1-G6)의 실험동물을 희생시키기 전 채취한 혈장에서의 염증 지표와 위 점막 보호 지표와 관련된 TNF$a, \mathrm{IL}-1 \beta, \mathrm{PGE} 2$ 및 VEGF를 측정하였다. 각각의 지표 측정 을 위해 TNF-a Platinum ELISA(eBioscience, San Diego, CA, USA), IL-1 $\beta$ Platinum ELISA(eBioscience), PGE2 ELISA kit(Abcam, Cambridge, UK) 및 VEGF Plantinum ELISA (eBioscience)를 사용하여 실험하였으며, ELISA reader (Tecan Austria GmbH, Grödig, Austria)를 이용하여 측정하 였다.

Real-time polymerase chain reaction에 의한 유 전자 발현 분석

6개 그룹(G1-G6)의 실험동물의 위에서 적출한 점막 부분 으로 TRI reagent ${ }^{\circledR}$ (Sigma-Aldrich)로 total RNA를 추출하고 cDNA는 Reverse Transcription System(Promega, Madison, WI, USA)으로 합성하였다. 합성된 cDNA는 TaqMan ${ }^{\circledR}$ Universal PCR master mixture(Applied Biosystems, Foster, CA, USA) 와 real-time PCR system(7500, Applied Biosystems, Foster, $\mathrm{CA}, \mathrm{USA}$ )을 사용하여 real-time $\mathrm{PCR}$ 을 수행하였다. Real-time PCR taqman probes는 Table 2에 나타내었으며, real-time PCR 조건은 $50^{\circ} \mathrm{C}$ 에서 1 분, $95^{\circ} \mathrm{C}$ 에서 10 분간 수행 한 후, $95^{\circ} \mathrm{C}$ 에서 15 초, $60^{\circ} \mathrm{C}$ 에서 1 분간 40 cycling으로 PCR 을 수행하였다.

Table 2. Real-time PCR taqman probes

\begin{tabular}{cccc}
\hline Gene nane & Assay ID & Dye & Manufacturer \\
\hline GAPDH & Rn01775763_g1 & VIC & \\
Histamine receptor H2 (H2r) & Rn00564216_s1 & FAM & Applied \\
Cholecystokinin 2 receptor (CCK-2r) & Rn00565867_m1 & VIC & Biosystems \\
H+/K+ ATPase & Rn00591698_m1 & FAM & \\
\hline
\end{tabular}

\section{통계처리}

본 연구결과에 대한 통계적 유의성은 SPSS(statistical package for social sciences, SPSS INC, ver.19.0, Chicago, IL, USA) package program을 이용하여 실험군 당 평균과 표준편차로 표시하였고, Student's t-test를 실시하여 $\mathrm{p}<0.05$ 수준에서 유의성을 검정하였다.

\section{결과 및 고찰}

까마귀쪽나무열매추출물 (LJF-HE)의 표준규격화 확인 까마귀쪽나무열매추출물(LJF-HE)에 대한 표준화는 지 표성분인 Hamabiwalactone $\mathrm{B}$ 의 함량범위를 식품의약품안 전처의 개별인정형 건강기능식품소재 개발에 적합하게 Hamabiwalactone $B$ 함량에 대한 평균값 $15.2 \mathrm{mg} / \mathrm{g}$ 의 
$80-120 \%$ 인 $12.1-18.3 \mathrm{mg} / \mathrm{g}$ 로 설정하여 확립하였으며, 본 연구에 사용한 까마귀쪽나무열매추출물(LJF-HE)의 지표 성분인 Hamabiwalactone B의 함량이 $15.2 \pm 0.1 \mathrm{mg} / \mathrm{g}$ 으로 분석되어 까마귀쪽나무열매추출물의 표준화 규격에 적합 한 것으로 확인하였으며, 본 연구에 사용하였다. 까마귀쪽 나무는 일본에서 hamabiwa로 불리우며, Hamabiwalactone $\mathrm{B}$ 는 lactone류의 일종으로 까마귀쪽나무 열매에 특이적으 로 함유되어 있어 까마귀쪽나무열매추출물의 지표성분으 로 설정하였으며, 이는 까마귀쪽나무열매주정추출물을 소 재화하여 관절염개선효능 연구에서도 Hamabiwalactone B 를 지표성분으로 설정하였으며 평균함량이 $15.9 \pm 0.009$ $\mathrm{mg} / \mathrm{g}$ 으로 제시(20)되어 본 연구에서의 함량과 유사하게 측 정되었다.

\section{인도메타신으로 유도된 위염모델에서의 위 염증}

위 기능 개선을 확인하기 위하여 인도메타신으로 유도된 위염 모델연구는 보편적인 방법 중에 하나로 다양한 연구자 들에 의해 수행되어져왔다(23,27). 까마귀쪽나무열매추출 물의 인도메타신으로 유도된 위염모델에서의 위 염증에 대해 육안 병변을 살펴본 결과 $\mathrm{G1}$ (normal) 그룹에서는 위 염증이 관찰되지 않은 반면, $\mathrm{G} 2$ (control) 그룹에서는 위 점막출혈을 관찰할 수 있었으며, 까마귀쪽나무열매추출물 그룹(G4, G5, G6)에서의 위염증과 점막출혈 부위가 $\mathrm{G} 2$ 그 룹에 비해 감소하였음을 관찰할 수 있었다(Table 3). $\mathrm{G}$ (control) 그룹의 위 염증 길이는 $17.2 \pm 4.0 \mathrm{~mm}$ 로 분석되 었으며, 양성대조군인 $\mathrm{G} 3$ (ranitidine) 그룹에서는 $4.7 \pm 1.8$ $\mathrm{mm}$ 로 $\mathrm{G} 2$ 군에 비해 통계적으로 유의성 있는 감소결과를 얻었다(p<0.01)(Table 3). 까마귀쪽나무열매추출물 그룹인 G4(LJF-HE-L), G5(LJF-HE-M) 및 G6(LJF-HE-H)에서 염증 의 길이는 각각 $11.1 \pm 1.2 \mathrm{~mm}, 11.1 \pm 2.6 \mathrm{~mm}, 8.0 \pm 1.5 \mathrm{~mm}$ 로 측정되었으며, G2 그룹에 비해 통계적으로 유의하게 감소 하였다 $(\mathrm{p}<0.05)($ Table 3$)$.

\section{위액량 (gastric juice volume) 및 펩신 활성도 변화}

실험 종료 후에 6 그룹의 실험동물에 대한 위액을 수집하 여 그 양을 측정한 결과, $\mathrm{G} 2$ 그룹의 위액량은 $7.3 \pm 1.3 \mathrm{~mL}$ 로 측정되어 $\mathrm{G} 1$ 그룹의 $3.2 \pm 1.7 \mathrm{~mL}$ 에 비해 증가하였으며, $\mathrm{G} 3$ 그룹의 위액량은 $1.8 \pm 0.7 \mathrm{~mL}$ 로 측정되어 $\mathrm{G} 2$ 그룹 대비 유의적으로 감소한 결과를 얻었다(p<0.001)(Table 4). 또한 까마귀쪽나무열매추출물 그룹인 G4(LJF-HE-L), G5(LJF$\mathrm{HE}-\mathrm{M})$ 및 G6(LJF-HE-H)에서 각각의 위액량은 $4.9 \pm 1.6 \mathrm{~mL}$, $4.9 \pm 1.1 \mathrm{~mL}, 4.8 \pm 1.4 \mathrm{~mL}$ 로 $\mathrm{G} 2$ 그룹 대비 유의적으로 감소한 결과를 얻었다 $(\mathrm{p}<0.05)($ Table 4$)$. 또한 펩신 활성도를 측정 한 결과, control 그룹의 펩신 활성도는 $52.1 \pm 3.2 \mathrm{mg}$ tyrosineproduced/h로 normal 그룹의 $42.1 \pm 3.6 \mathrm{mg}$ tyrosine produced/h에 비해 증가한 결과를 얻었으며, ranitidine 그룹 은 $48.4 \pm 2.4 \mathrm{mg}$ tyrosine produced/h로 control 그룹 대비
Table 3. Effect of Litsea japonica fruit extract (LJF-HE) on ulcer length $(\mathrm{mm})$ and Inhibition rate $(\%)$ in rats with indomethacininduced gastritis

\begin{tabular}{cccc}
\hline & Group & $\begin{array}{c}\text { Ulcer length } \\
(\mathrm{mm})\end{array}$ & $\begin{array}{c}\text { Inhibition rate } \\
(\%)\end{array}$ \\
\hline G1 & Normal & $0.2 \pm 0.4^{\left.2)^{* * * 3}\right)}$ & 99.0 \\
G2 & Control & $17.2 \pm 4.0$ & 0 \\
G3 & Ranitidine 50mg/kg & $4.7 \pm 1.8^{* *}$ & 73.0 \\
G4 & LIF-HE-L & $11.1 \pm 1.2^{*}$ & 35.3 \\
G5 & LIF-HE-M & $11.1 \pm 2.6^{*}$ & 35.3 \\
G6 & LIF-HE-H & $8.0 \pm 1.5^{*}$ & 53.6 \\
\hline
\end{tabular}

${ }^{1)} \mathrm{G} 1$ (normal, vehicle), G2 (control, indomethacin-induced gastritis), G3 (ranitidine $50 \mathrm{mg} / \mathrm{kg}$, indomethacin-induced gastritis and pretreatment of ranitidine $50 \mathrm{mg} / \mathrm{kg}$ ), G4 (LFF-HE-L, indomethacin-induced gastritis and pretreatment of LFF-HE $30 \mathrm{mg} / \mathrm{kg}$ ), G5 (LFF-HE-M, indomethacin-induced gastritis and pretreatment of LJF-HE $60 \mathrm{mg} / \mathrm{kg}$ ), G6 (LJF-HE-H, indomethacin-induced gastritis and pretreatment of LJF-HE 120 $\mathrm{mg} / \mathrm{kg}$ ) groups.

${ }^{2)}$ The values are mean $\pm \mathrm{SD}$.

${ }^{3)}$ Significant difference from control group by Student's t-est: ${ }^{*} \mathrm{p}<0.05,{ }^{* *} \mathrm{p}<0.005$, $\mathrm{p}<0.001$.

감소한 결과를 얻었다(Table 4). 또한 까마귀쪽나무열매추 출물 저농도(G4), 중농도(G5), 고농도(G6) 그룹에서 펩신 활성도는 각각 $41.4 \pm 6.4,35.2 \pm 3.6,34.6 \pm 3.6 \mathrm{mg}$ tyrosine produced/h로 control 대비 유의성 있게 감소하는 것으로 나타났다(Table 4).

Table 4. The changes of gastric juice volume and pepsin activity of gastric juice in rats with indomethacin-induced gastritis

\begin{tabular}{cccc}
\hline & Group & $\begin{array}{c}\text { Gastric juice } \\
\text { vol. }(\mathrm{mL})\end{array}$ & $\begin{array}{c}\text { Pepsin activity } \\
(\mathrm{mg} \text { tyrosine produced/h) }\end{array}$ \\
\hline $\mathrm{G1}^{1)}$ & Normal & $3.2 \pm 1.7^{\left.2)^{* * 3}\right)}$ & $42.2 \pm 3.6^{* *}$ \\
G2 & Control & $7.3 \pm 1.3$ & $52.1 \pm 3.2$ \\
G3 & Ranitidine 50mg/kg & $1.8 \pm 0.7^{* * *}$ & $48.4 \pm 2.4^{*}$ \\
G4 & LIF-HE-L & $4.9 \pm 1.6$ & $41.4 \pm 6.4^{* *}$ \\
G5 & LIF-HE-M & $4.9 \pm 1.1^{*}$ & $35.2 \pm 3.6^{* * *}$ \\
G6 & LIF-HE-H & $4.8 \pm 1.4^{*}$ & $34.6 \pm 3.6^{* * *}$ \\
\hline
\end{tabular}

${ }^{1)} \mathrm{G} 1$ (normal, vehicle), G2 (control, indomethacin-induced gastritis), G3 (ranitidine $50 \mathrm{mg} / \mathrm{kg}$, indomethacin-induced gastritis and pretreatment of ranitidine $50 \mathrm{mg} / \mathrm{kg}$ ), G4 (LFF-HE-L, indomethacin-induced gastritis and pretreatment of LF-HE $30 \mathrm{mg} / \mathrm{kg}$ ), G5 (LFF-HE-M, indomethacin-induced gastritis and pretreatment of LFF-HE $60 \mathrm{mg} / \mathrm{kg}$ ), G6 (LJF-HE-H, indomethacin-induced gastritis and pretreatment of LJF-HE 120 $\mathrm{mg} / \mathrm{kg}$ ) groups.

${ }^{2}$ The values are mean $\pm S D$.

${ }^{3)}$ Significant difference from control group by Student's t-test: ${ }^{*} \mathrm{p}<0.05,{ }^{* *} \mathrm{p}<0.005$, $\mathrm{p}<0.001$.

위염은 위 점막에 염증세포의 침윤이 있는 염증의 상태 로 외부 인자에 대한 비 특이적인 반응으로 나타나는 증상 으로, 위 점막의 손상은 위 점막을 보호하는 방어인자(프로 스타글라딘, 상피세포, 점액 등)와 위 점막을 손상시키는 공격인자(비스테로이드성 항염제, 헬리코박터 파이로니, 위산, 펩신 등) 사이의 균형이 깨져서 위염이 유발된다. 
방어인자와 공격인자의 불균형으로 인한 위 점막 손상이 발생하면 위산이나 펩신분비가 증가하여 위 점막 손상이 악화되는 것으로 알려져 있다. 위산이나 펩신은 과다 분비 되거나 방어인자가 약해졌을 때 공격인자로 작용하여 자기 소화(autolysis) 작용을 통해 위 점막에 손상을 일으킨다 $(28,29)$. 또한 위에서 분비되는 펩시노겐은 위산으로 인한 강한 산성상태에서 펩신으로 활성화되며, 펩신은 단백질 분해 작용을 한다. 따라서 펩신 활성이 증가하면 단백질 분해활성이 증진되는 효과를 나타낸다(30). 반면에 위산과 마찬가지로 위 손상 발생 시에는 펩신 활성을 감소시키는 것이 위 손상을 악화시키지 않는데 도움을 줄 수 있다.

본 연구에서와 같이 인도메타신 유발에 의한 위염은 화 학물질에 의한 급성손상으로 점막의 표층이 손상되거나 궤양을 동반한다. 위 손상이 있는 경우 위액이 많이 분비될 수록 손상을 악화시키므로 위액분비량이 감소될 경우 위손 상이 예방될 것이다(31,32). 따라서 까마귀쪽나무열매추출 물(LJF-HE)은 인도메타신으로 유발되어진 위염모델에서 위액량의 유의적인 감소효과로 위산분비가 억제되어
공격인자 작용이 약해져서 위염발생을 억제하는 것으로 사료되어지며, 또한 펩신의 활성도를 낮추어 위염발생을 억제하는 것으로 판단되어진다.

\section{혈장 위염지표분석}

인도메타신으로 유도된 위염 모델에서 까마귀쪽나무열 매추출물(LJF-HE)의 위 점막 보호 및 염증 개선 기전을 확인하기 위하여, 실험동물의 혈장 내에 존재하는 PGE2, VEGF, TNF-a, IL-1 $\beta$ 등을 측정한 결과, G5와 G6 그룹에서 세포보호물질로 점액 및 혈류량을 증가시켜 위 점막을 보호 하는 역할을 하는 PGE2의 혈장 내 함량이 대조군에 비해 유의적으로 증가하였다(Fig. 1A). 반면에 모든 실험군에서 점막조직 생성을 촉진하는 $\mathrm{VEGF}$ 의 혈장 내 농도는 유의적 인 차이를 보이지 않았다(Fig. 1B). 까마귀쪽나무열매추출 물(G4, G5, G6) 그룹은 염증성 cytokine중에 하나인 TNF-a 의 혈장 내 함량을 대조군에 비해 유의적으로 감소하였다 (Fig. 1C). 또한, 또 다른 염증성 cytokine중에 하나인 IL-1ß 의 혈장 내 함량은 까마귀쪽나무열매추출물 $(\mathrm{G} 5, \mathrm{G} 6)$ 그룹
A

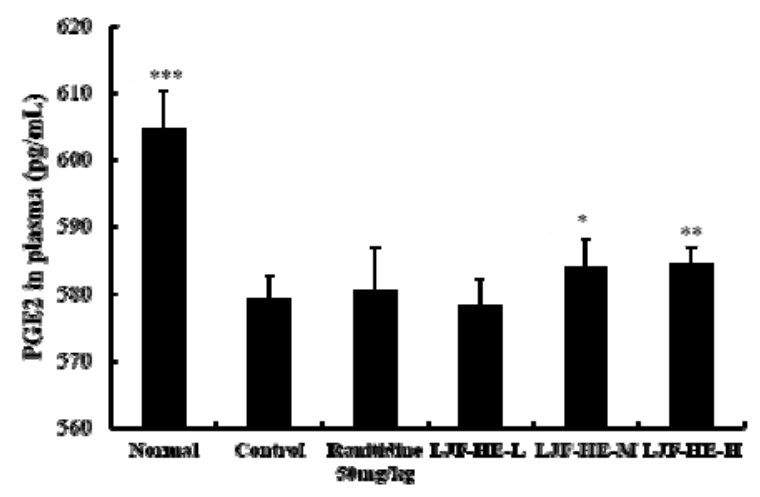

C

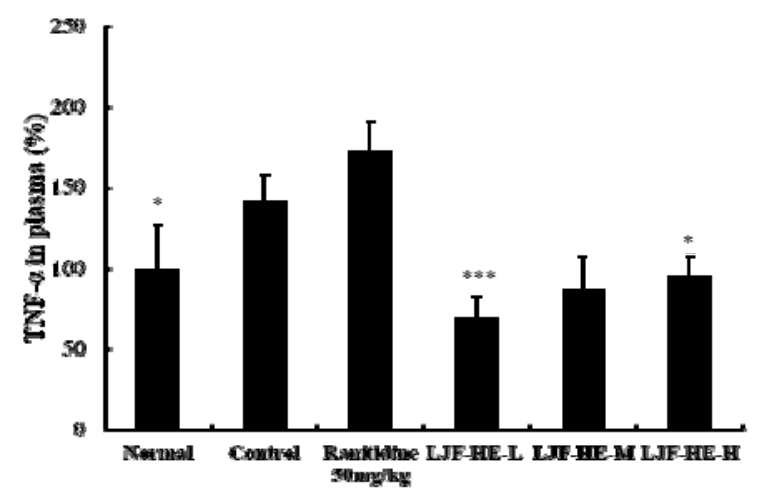

B

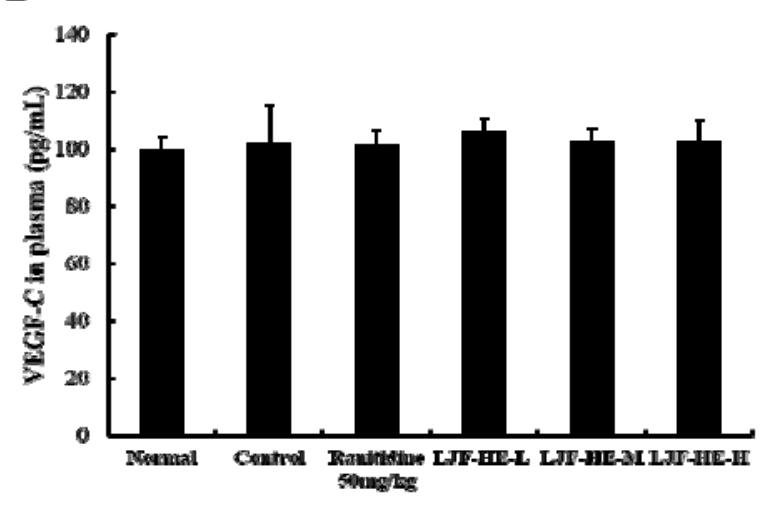

D

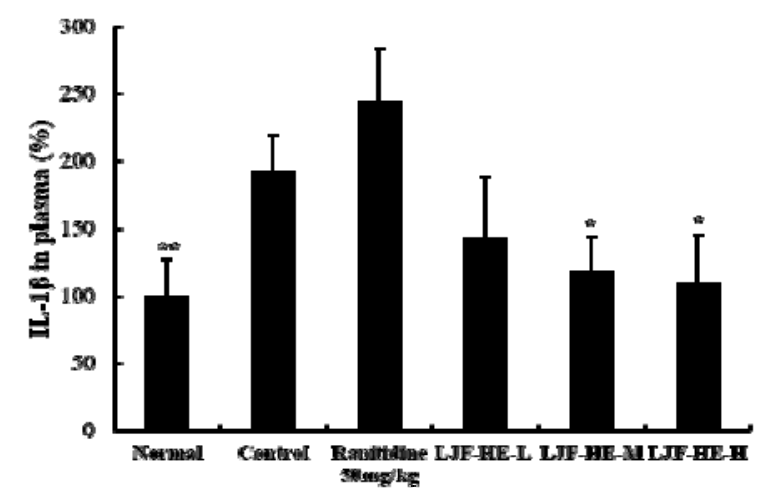

Fig. 1. Effects of Litsea japonica fruit flesh extract (LJF-HE) on plasma PGE2 (A), plasma VEGF (B), plasma TNF-a (C), and plasma IL-1 $\beta$ (D) in rats.

Normal (vehicle), control (indomethacin-induced gastritis), ranitidine $50 \mathrm{mg} / \mathrm{kg}$ (indomethacin-induced gastritis and pretreatment of ranitidine $50 \mathrm{mg} / \mathrm{kg}$ ), LJF-HE-L (indomethacin-induced gastritis and pretreatment of LJF-HE $30 \mathrm{mg} / \mathrm{kg}$ ), LJF-HE-M (indomethacin-induced gastritis and pretreatment of LJF-HE $60 \mathrm{mg} / \mathrm{kg}$ ), LJF-HE-H (indomethacin-induced gastritis and pretreatment of LJF-HE $120 \mathrm{mg} / \mathrm{kg}$ ) groups.

The values are mean \pm SD. Significant difference from control group by Student's t-test: $* \mathrm{p}<0.05, * * \mathrm{p}<0.005 . * * * \mathrm{p}<0.001$. 
에서 대조군에 비해 유의적으로 감소하였다(Fig. 1D). 이러 한 결과들로 볼 때, 인도메타신으로 유도된 위염 모델에서 LJF-HE는 점액을 증가시켜 위 점막을 보호하는 PGE2의 함량을 높여, 위 점막 보호 기능을 나타내고 있으며, 더불어 염증성 cytokine인 TNF- $a$ 와 IL- $1 \beta$ 의 생성을 낮춰주어 염증 매개반응을 저해하는 것으로 판단되어진다.

\section{위 점막 유전자 발현 분석}

인도메타신으로 유도된 위염 모델에서 까마귀쪽나무열 매추출물(LJF-HE)의 위산 분비 억제 기전을 확인하기 위하 여, 실험동물의 위 조직으로 부터 total RNA를 분리하여, real-time $\mathrm{PCR}$ 을 통해 histamine receptor $\mathrm{H} 2(\mathrm{H} 2 \mathrm{r})$, cholecystokinin 2 receptor(CCK-2r), $\mathrm{H}+/ \mathrm{K}+$ ATPase 등을 housekeeping gene인 GAPDH와 비교하여 상대적인 mRNA level을 측정한 결과, $\mathrm{G} 3(0.33 \pm 0.39)$ 그룹과 $\mathrm{G} 4(0.51 \pm 0.40)$, $\mathrm{G} 5(0.56 \pm 0.50), \mathrm{G} 6(0.34 \pm 0.38)$ 그룹에서 gastrin에 의해 활 성화 되는 CCK-2r 유전자 발현이 G2(1.39 \pm 0.61$)$ 에 비해 유의적으로 억제되는 것으로 나타났으며, 이는 G1(0.29 \pm 0.35 )과 유사한 수준으로 나타났다(Fig. 2A). 또한 histamine
에 의해 발현되는 $\mathrm{H} 2 \mathrm{r}$ 유전자 발현도 $\mathrm{G} 3(0.50 \pm 0.21)$ 그룹과 $\mathrm{G} 4(0.57 \pm 0.24), \mathrm{G} 5(0.42 \pm 0.15), \mathrm{G} 6(0.35 \pm 0.14)$ 그룹에서 $\mathrm{G} 2(1.43 \pm 0.51)$ 에 비해 유의적으로 억제 되었으며(Fig. 2B), cAMP와 $\mathrm{Ca} 2+$ 농도 증가 등에 의해 활성화 되어 $\mathrm{HCl}$ 분비 를 증가시키는 $\mathrm{H}+/ \mathrm{K}+$ ATPase 유전자 발현에서는 $\mathrm{G} 4$ $(0.58 \pm 0.27), \mathrm{G} 5(0.68 \pm 0.31), \mathrm{G} 6(0.80 \pm 0.29)$ 그룹에서 대조 군에 비해 유의적으로 억제되는 것으로 나타났다(Fig. $2 \mathrm{C}$ ). 위산 분비는 스트레스 등의 다양한 원인에 의해 히스타민, 아세틸콜린, gastrin 분비가 증가되고 관련 수용체인 $\mathrm{H} 2 \mathrm{r}$ 및 CCK-2ro이 증가되면서 가중된다 $(33,34)$. 이렇게 증가된 위산은 위의 공격인자로 작용하여 위 점막 손상을 야기한다 (35). 본 연구에서와 같이 인도메타신으로 유발되어지는위 손상 모델에서 까마귀쪽나무열매추출물(LJF-HE)의 위산 분비 억제 기능은 gastrin 및 histamine에 의해 발현되는 CCK-2r와 $\mathrm{H} 2 \mathrm{r}$ 유전자의 발현을 억제하여, gastrin 및 histamine에 의한 위산 생성 단계를 조절하여, proton pump 인 $\mathrm{H}+/ \mathrm{K}+$ ATPase 유전자 발현을 억제시키며, 그 결과로 인하여 위산 분비를 억제하는 것으로 판단되어진다.
A

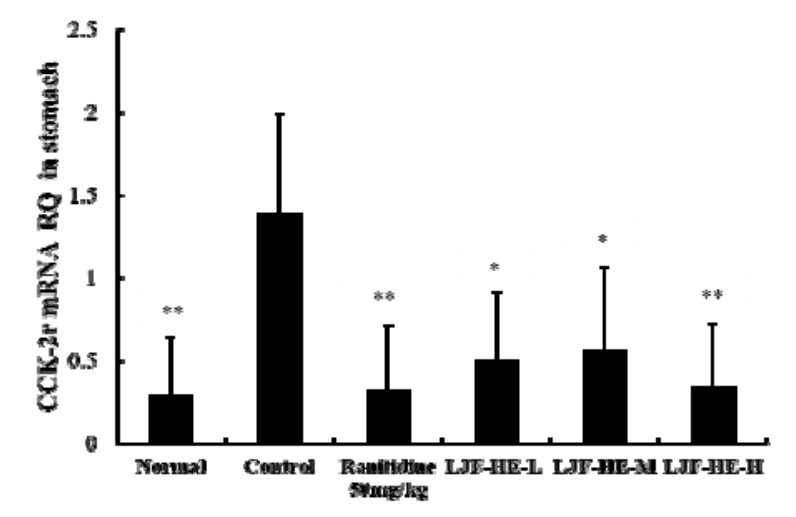

c

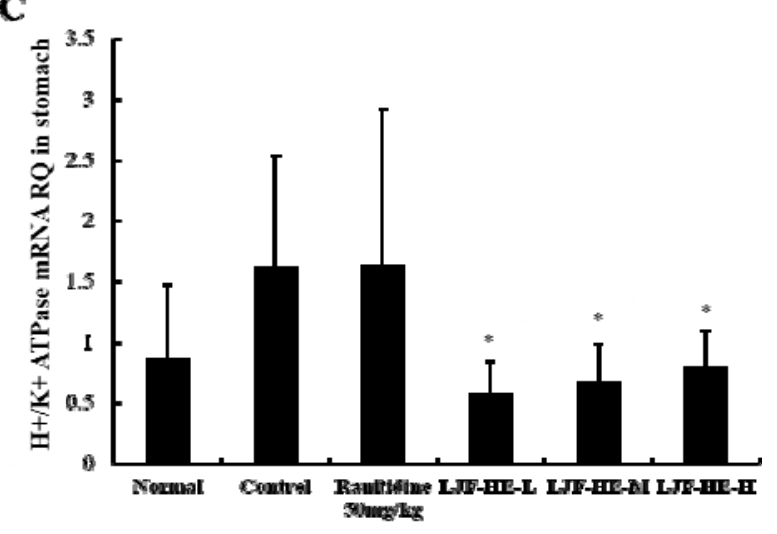

B

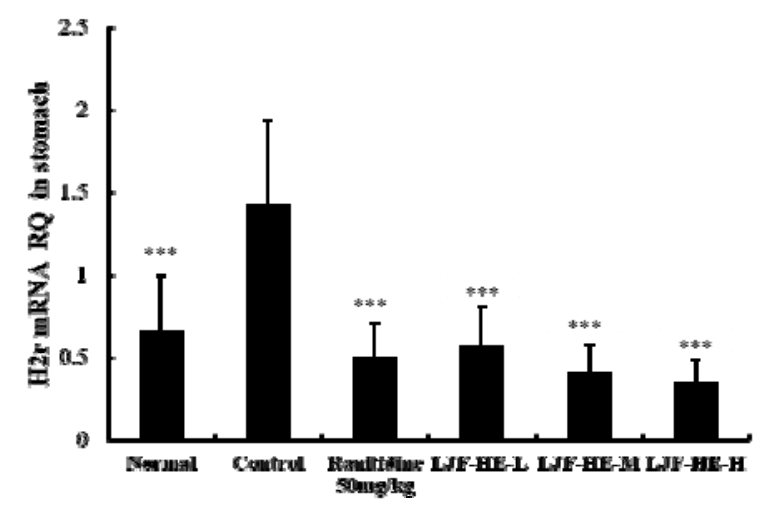

Fig. 2. Effect of Litsea japonica fruit flesh extract (LJF-HE) on CCK-2r (A), H2r (B), and H+/K+ ATPase (C) expression in rats.

Normal (vehicle), control (indomethacin-induced gastritis), ranitidine $50 \mathrm{mg} / \mathrm{kg}$ (indomethacin-induced gastritis and pretreatment of ranitidine $50 \mathrm{mg} / \mathrm{kg}$ ), LJF-HE-L (indomethacin-induced gastritis and pretreatment of LJF-HE $30 \mathrm{mg} / \mathrm{kg}$ ), LJF-HE-M (indomethacin-induced gastritis and pretreatment of LJF-HE $60 \mathrm{mg} / \mathrm{kg}$ ), LJF-HE-H (indomethacin-induced gastritis and pretreatment of LJF-HE $120 \mathrm{mg} / \mathrm{kg}$ ) groups.

The values are mean $\pm S D$. Significant difference from control group by Student's t-test: * $p<0.05,{ }^{* *} p<0.005,{ }^{* * *} p<0.001$. 


\section{요 약}

본 연구에서는 까마귀쪽나무열매추출물(LJF-HE)의 흰 쥐모델에서 인도메타신으로 유발되어지는 위염에 대한 억 제효과를 확인하고자 하였다. 까마귀쪽나무열매추출물 투 여그룹(LJF-HE-L, LJF-HE-M, LJF-HE-H)에서 염증길이와 위액량이 control 그룹에 비하여 통계적으로 유의하게 감소 한 결과를 얻었다. 또한 위액량의 유의적인 감소효과로 위 산분비가 억제되어 공격인자 작용이 약해지는 원인과 펩신 의 활성도를 낮추는 원인으로 인하여 위염발생을 억제하는 것으로 판단되어진다. 까마귀쪽나무열매추출물(LJF-HE) 의 위산 분비 억제 기능은 gastrin 및 histamine에 의해 발현 되는 CCK-2r와 H2r 유전자의 발현을 억제하여, gastrin 및 histamine에 의한 위산 생성 단계를 조절하여, proton pump 인 $\mathrm{H}+/ \mathrm{K}+$ ATPase 유전자 발현을 억제시키며, 그 결과로 인하여 위산 분비를 억제하는 것으로 판단되어진다. 그리 고 까마귀쪽나무열매추출물은 점액을 증가시켜 위 점막을 보호하는 PGE2의 함량을 높여, 위 점막 보호 기능을 나타내 고 있으며, 더불어 염증성 cytokine인 TNF- $\alpha$ 와 IL- $1 \beta$ 의 생 성을 낮춰주어 염증 매개반응을 저해하는 것으로 판단되어 진다. 이와 같은 결과를 종합하면 까마귀쪽나무열매추출물 (LJF-HE)이 인도메타신으로 유발되어지는 위염에 대한 억 제효과가 있는 것으로 판단되었다.

\section{감사의 글}

본 연구는 중소벤처기업부 중소기업기술혁신개발사업 (과제번호: S2314842)의 지원에 의하여 이루어진 것으로 연구비 지원에 감사드립니다.

\section{References}

1. Glickman JN, Antonioli DA (2001) Gastritis. Gastrointest Endosc Clin North Am, 11, 717-740

2. Aro P, Talley NJ, Ronkainen J, Storskrubb T, Vieth M, Johansson SE, Bolling-Sternevald E, Agreus L (2009) Anxiety is associated with uninvestigated and functionalepsia (ROME III criteria) in a Swedish population based study. Gastroenterol, 137, 94-100

3. Srivastava A, Lauwers GY (2007) Pathology of non-infective gastritis. Histopathology, 50, 15-29

4. Franke A, Teyssen S, Singer MV (2005) Alcohol-related diseases of the esophagus and stomach. Dig Dis, 23, 204-213

5. Dajani EZ, Islam K (2008) Cardiovascular and gastrointestinal toxicity of selective cyclo-oxygenase-2 inhibitors in man. J Physiol Pharmacol, 59(Suppl 2), 117-133

6. Siegelbaum, Jackson (2006) Gastritis. Jackson Siegelbaum Gastroenterology. https://www.gicare.com/

7. Fullarton GM, McLauchlan G, Macdonald A, Crean GP, McColl KEL (1989) Rebound nocturnal hypersecretion after four weeks treatment with an $\mathrm{H} 2$ receptor antagonist. Gut, 30, 449-454

8. Szabo S, Bynum TE (1988) Alternatives to the acid-oriented approach to ulcer disease: does 'cytoprotection' exist in man? A new classification of antiulcer agents. Scand J Gastroenterol, 23, 1-6

9. Berardi RR, Savitsky ME, Nostrant TT (1987) Maintenance therapy for prevention of recurrent peptic ulcers. Drug Intell Clin Pharm, 21, 493-501

10. Raveendra KR, Srinivasa V, Sushma KR, Allan JJ, Goudar KS, Shivaprasad HN, Venkateshwarlu K, Geetharani P, Sushma G, Agarwal A (2012) An extract of Glycyrrhiza glabra (GutGard) alleviates symptoms of functional dyspepsia: a randomized, double-blind, placebo-controlled study. Evidence-Based Complementary and Alternative Medicine, 2012, 216970

11. Mukherjee M, Bhaskaran N, Srinath R, Shivaprasad HN, Allan JJ, Shekhar D, Agarwal A (2010) Anti-ulcer and antioxidant activity of GutGardTM, Indian J Exp Biol, 48, 269-274

12. Dabos KJ, Sfika E, Vlatta LJ, Frantzi D, Amygdalos GI, Giannikopoulos G (2010) Is Chios mastic gum effective in the treatment of functional dyspepsia? A prospective randomised double-blind placebo controlled trial. J ethnopharmacology, 127, 205-209

13. Nam DE, Kim OK, Shim TJ, Lee JK, Hwang KT (2014) Inhibitory effects of Chios Mastic gum on gastric acid secretion by histamine related pathway in a rat model and primary parietal cells. J Korean Soc Food Sci Nutr, 43, 1500-1509

14. Fernandez-Travieso JC, Rodríguez-Cortina I, IllnaitFerrer J, Fernandez-Dorta L, Mas-Ferreiro R, PerezGuerra Y, Gamez-Menéndez R, Mesa-Angarica M, Jimenez-Despaigne S, Mendoza-Castano S, Ruiz-Mas D (2012) Effects of Abexol ${ }^{\circledR}$ (beeswax alcohols) in patients with gastric symptoms. Revista CENIC Ciencias Biológicas, 43, 9-16

15. Carbajal-Quintana D, Molina-Cuevas V, Ravelo-Calzado Y, Mas-Ferreiro R (2013) Effects of D-002, a mixture of beeswax alcohols, on the acetic acid-induced writhing 
test in mice: a comparison with naproxen, aspirin, and paracetamol. Revista CENIC Cienc Biol, 44

16. Holtmann G, Adam B, Haag S, Collet W, Grunewald E, Windeck T (2003) Efficacy of artichoke leaf extract in the treatment of patients with functional dyspepsia: a six week placebo controlled, double blind, multicentre trial. Aliment Pharmacol Ther, 18, 1099-1105

17. Min BS, Lee SY, Kim JH, Kwon OK, Park BY, An RB, Lee JK, Moon HI, Kim TJ, Kim YH, Joung H, Lee HK (2003) Lactones from the leaves of the Litsea japonica and their anti-complement activity. J Nat Prod, $66,1388-1390$

18. Kim SH, Choi HJ, Yang WK, Lee JE, Cho JH, Park IJ, Park SY, Park BK, Jin M (2017) Suppressive effect of the n-hexane extract of Litsea japonica fruit flesh on monosodium-iodoacetate-induced osteoarthritis in rats. Evidence-Based Complementary Altern Medi, 2017, Article ID 1791403, p 10

19. Ahn YS, Kwon OR, Kim EA, Yoon WJ, Kim JH, Kim JY (2017) Randomized double-blind placebo-controlled study of the efficacy of Litsea japonica fruit extract in subjects with mild to moderate knee osteoarthritis. J Funct Foods, 34, 304-310

20. Jeong YJ, Kim IH, Cho JH, Park DW, Kwon JE, Jung MW, Meng X, Jo SM, Song HS, Cho YM, Song SM, Ham YM, Jung YH, Kim CS, Yoon WJ, Kang SC (2015) Anti-osteoarthritic effects of the Litsea japonica fruit in a rat model of osteoarthritis induced by monosodium iodoacetate. PLoS One, 10, e0134856

21. Yoon WJ, Song SM, Ham YM, Oh DJ, Ko CS, Yoon SA, Lee YB, Park DW, Jeong YJ, Kwon JE, Cho YM, Cho JH, Kim CS, Kang SC (2015) Anti-osteoarthritis effects on fruit extract of Litsea japonica. Korean J Plant Reso, 28, 591-599

22. JimEnez-PErez NDC, Lorea-HernAndez FG, Jankowski CK, Reyes-Chilpa R (2011) Essential oils in Mexican bays (Litsea spp., Lauraceae): taxonomic assortment and ethnobotanical implications. Econ bot, 65, 178-189

23. Urushidani T, Okabe S, Takeuchi K, Takagi K (1977) Effects of various amino acids on indomethacin-induced gastric ulcers in rats. The Jpn J Pharmacol, 27, 316-319
24. Jeong CH, Hyun JE, Kang MH, Kim HP, Park JM, Lee SY (2002) Antigastritic and Anti-ulcerative effect of P020701. Kor J Parmacogn, 33, 389-394

25. Kurebayashi Y, Ikeda T, Osada Y (1988) Cytoprotective action of cetrexate against $\mathrm{HCl}$-ethanol induced gastric lesion in rats. The Jpn J Pharmacol, 46, 17-25

26. Anson ML (1938) The estimation of pepsin, trypsin, papain, and cathepsin with hemoglobin. J gen physiol, 22, 79-89

27. Lee JJ, Choi HS, Lee JH, Jung CJ, Lee MY (2005) The effects of ethylacetate fraction of Sanguisorba officinalis L. on experimentally-induced acute gastritis and peptic ulcers in rats. J Korean Soc Food Sci Nutri, 34, 1545-1552

28. Korea Food and Drug Administration (2016) Guidance for evaluation on efficacy of health functional food (can help improve stomach health or digestion). Korea Food and Drug Administration

29. Okabe S, Jino H, Nishida A (1986) Effects of 15 (R)-15-methyl prostaglandin $\mathrm{E}_{2}$ (arbaprostil) on gastric secretion and various gastric lesions induced in rats. Jpn J Pharmacol, 40, 329-337

30. Seijffers MJ, Segal HL, Miller LL (1963) Separation of pepsinogen I, pepsinogen II, and pepsinogen III from human gastric mucosa. Am J Physiol, 205, 1106-1112

31. Kim DB, Sin DG (2004) Functional testing guide of functional health food. Korea Health Supplement Association, Seoul, Korea. p 554-559

32. Kim SJ, Kim YG, Park KY (2012) Inhibitory Effects of Ginger and Processed (Beopje) Ginger Extracts on HCl-ethanol Induced Gastritis in Rats. J Korean Soc Food Sci Nutr, 41, 1528-1533

33. Chen D, Zhao CM (2010) Complexity of gastric acid secretion revealed by targeted gene disruption in mice. Curr Pharm Des, 16, 1235-1240

34. Schubert ML (2007) Gastric secretion. Curr Opin Gastroenterol, 23, 595-601

35. Osawa H, Kita H, Ohnishi $\mathrm{H}$, Hoshino $\mathrm{H}$, Mutoh $\mathrm{H}$, Ishino Y, Watanabe E, Satoh K, Sugano K (2006) Helicobacter pylori eradication induces marked increase in $\mathrm{H}^{+} / \mathrm{K}^{+}$adenosine triphosphatase expression without altering parietal cell number in human gastric mucosa. Gut, 55, 152-157 